\title{
Pemanfaatan Kompos Tandan Kosong Kelapa Sawit Plus (KOTAKPLUS) terhadap Produksi Kedelai (Glycine max L.) pada Tanah Ultisol
}

\author{
A. Haitami*, Wahyudi \\ Fakultas Pertanian, Universitas Islam Kuantan Singingi \\ *thaitami@yahoo.com
}

\begin{abstract}
Abstrak. Penelitian ini bertujuan untuk mengetahui dosis penggunaan pupuk kompos tandan kosong kelapa sawit plus (KOTAKPLUS) pada produksi tanaman kedelai. Penelitian ini dilakukan di BBI Sungai Rumbio Desa Koto Kari Kecamatan Kuantan Tengah Kabupaten Kuantan Singingi. Penelitian ini menggunakan Rancangan Acak Kelompok (RAK) yang terdiri dari 6 taraf perlakuan dan 3 kelompok sehingga terdapat 18 unit satuan percobaan. Perlakuan yang diberikan adalah: $\mathrm{A}=$ Tanpa masukan apapun (kontrol). $\mathrm{B}=$ KOTAKPLUS 10 ton/ha $+100 \%$ pupuk anorganik, $\mathrm{C}=$ KOTAKPLUS 20 ton/ha $+100 \%$ pupuk anorganik, $\mathrm{D}=$ KOTAKPLUS 30 ton/ha $+100 \%$ pupuk anorganik, $\mathrm{E}=$ Kompos tandan kosong kelapa sawit saja 20 ton/ha $+100 \%$ pupuk anorganik, $\mathrm{F}=100 \%$ pupuk anorganik. Hasil pengamatan pada masing-masing perlakuan dianalisis secara statistic dengan analisis sidik ragam (ANSIRA), kemudian dilanjutkan dengan Uji Lanjut Beda Nyata Jujur (BNJ) pada taraf $5 \%$. Berdasarkan hasil penelitian yang telah dilakukan bahwa perlakuan D merupakan perlakuan terbaik terhadap parameter tinggi tanaman umur 14, 28, 42 HST, (cm), Jumlah Polong pertanaman (buah), Berat Biji pertanaman (gram), dan Berat 100 Biji (gram).
\end{abstract}

Kata Kunci: kedelai, empty fruit bunch, kompos, KOTAKPLUS, ultisol

\section{PENDAHULUAN}

Provinsi Riau yang memiliki 10 Kabupaten yang salah satunya adalah Kabupaten Kuantan Singingi yang sering mengalami rawan pangan karena sebagian besar luas tanahnya didominasi oleh komoditi tanaman perkebunan seperti tanaman kelapa sawit, karet dan kakao, maka lahan pertanian yang dijadikan petani untuk bercocok tanam tanaman pangan menjadi sangat sempit dan terbatas. Berdasarkan penyebaran group tanah, Kabupaten Kuantan Singingi didominasi oleh dataran tuf masam yakni sekitar 31,80 \% dan sebagian besar memiliki tingkat kemasaman tanah sekitar 4,7-5. Secara umum tanah yang ada di kabupaten Kuantan Singingi menurut data laporan Dinas tanaman pangan tahun 2013 Kuantan Singingi didominasi oleh tanah Podsolik merah kuning atau dalam klasifikasi taxonomi dikenal dengan ordo tanah ultisol.

Menurut Hakim (2006) tanah ultisol merupakan tanah yang memiliki pH tanah rendah, kandungan bahan organik rendah, defisisensi $\mathrm{P}$, keracunan $\mathrm{Al}$, dan kandungan unsur hara makro lainnya juga rendah. Melakukan budidaya tanaman perkebunan pada tanah ultisol tidak mendapatkan kesulitan, dikarenakan tanah ultisol lebih cocok untuk komoditi tanaman perkebunan, akan tetapi untuk tanaman pangan seperti kedelai, umumnya masih terkendala oleh sifat-sifat kimia tersebut. Untuk itu perlu mencari sumber bahan organik yang dibutuhkan untuk menyelesaikan permasalahan pada tanah ultisol. Bahan organik yang berpotensi di Kabupaten Kuantan Singingi adalah limbah padat pabrik kelapa sawit yaitu tandan kosong kelapa sawit. Berdasarkan data laporan dari dinas perkebunan kabupaten Kuantan Singingi tahun 2015.

Kabupaten Kuantan Singingi memiliki luas areal kelapa sawit sebesar 128.806,94 ha dengan produksi 455.491,94 ton. Kemudian, menurut database dinas perkebunan Kabupaten Kuantan Singingi tahun 2015 telah terdapat 21 perusahaan perkebunan kelapa sawit dan 18 Pabrik Kelapa Sawit (PKS) dengan kapasitas produksi 465 ton/ha di kabupaten Kuantan Singingi. Tandan kosong kelapa sawit merupakan limbah utama dari industri pengolahan kelapa sawit. Basis satu ton tandan buah segar (TBS) yang diolah akan dihasilkan minyak sawit kasar (CPO) sebanyak 0,21 ton $(21 \%)$ serta minyak inti sawit (PKO) sebanyak 0,05 ton (5\%) dan sisanya merupakan limbah dalam bentuk tandan buah kosong, serat, dan cangkang biji yang jumlahnya

To cite this article: Haitami, A., dan Wahyudi. 2019. Pemberian Pupuk Kompos Solid Pemanfaatan Kompos Tandan Kosong Kelapa Sawit Plus (KOTAKPLUS) terhadap Produksi Kedelai (Glycine max L.) pada Tanah Ultisol. Unri Conference Series: Agriculture and Food Security 1: 220-225. https://doi.org/10.31258/unricsagr.1.a28 
masing-masing 23\%, 13,5\%, dan 5,5\% dari tandan buah segar (Darmosarkoro dan Winarna, 2007). Pemanfaatan limbah tandan kosong kelapa sawit sebagai alternatif pupuk organik juga akan memberikan manfaat lain dari sisi ekonomi. Untuk perkebunan kelapa sawit pemanfaatan limbah tandan kosong kelapa sawit dapat menghemat penggunaan pupuk sintetis sampai 50\% (Fauzi et al., 2008). Kandungan yang kaya akan Fospor dan kalium yang dapat dimanfaatkan untuk meningkatkan kandungan hara kompos tandan kosong kelapa sawit adalah kotoran ayam.

Hardjowigeno (2010) menyatakan bahwa dalam semua pupuk kandang P selalu terdapat dalam kotoran padat. Pupuk kotoran ayam mengandung P sepuluh kali lebih banyak daripada kotoran sapi. Pemanfaatan limbah tandan kosong kelapa sawit sebagai alternatif pupuk organik dan juga dapat memberikan manfaat lain dari sisi ekonomi bagi petani. Kompos tandan kosong kelapa sawit (KOTAKPLUS) yang juga terkandung kotoran ayam dan kapur dolomite ini disebut dengan kompos tandan kosong kelapa sawit plus (KOTAKPLUS) yang mampu memberi solusi pemberian bahan organik pada budidaya tanaman kedelai ditanah ultisol. Tanaman kedelai juga merupakan tanaman leguminosa yang mempunyai bakteri rhizobium yang memiliki bintil akar yang berpotensi menambat Nitrogen. Produksi tanaman kedelai di provinsi Riau pada lima tahun terakhir ini cenderung mengalami penurunan, pada tahun 2011 adalah 7100 ton, kemudian turun pada tahun 2012 yaitu 4182 ton, semakin turun pada tahun 2013 yaitu 2212 ton, kemudian pada tahun 2014 semakin turun yaitu 2332 ton, dan semakin menurun pada tahun 2015 yaitu 2145 ton (Badan Pusat Statistik, 2015). Produktivitas yang rendah ini memang disebabkan oleh masalah tanah yang kurang subur dan miskin bahan organik, serta pengetahuan petani yang masih labil, sehingga produksi tanaman kedelai cenderung menurun dari tahun ke tahun.

\section{METODE}

Penelitian ini telah dilaksanakan pada jenis tanah Ultisol di BBI Desa Koto Kari Kecamatan Kuantan Tengah Kabupaten Kuantan Singingi dan analisa kompos dan tanah di lakukan di Laboratorium Kimia Tanah Fakultas pertanian Universitas Andalas Padang. Penelitian dilaksanakan selama 7 bulan, yaitu 3 bulan pembuatan kompos KOTAKPLUS dan kompos TKKS saja, dan selanjutnya 4 bulan penelitian dilapangan.

Adapun bahan yang digunakan pada penelitian ini adalah pupuk kompos KOTAKPLUS, pupuk kompos TKKS saja, tanah ultisol, benih kedelai varietas Demas 1, dolomite, pupuk anorganik Urea, SP-36 dan KCl. Alat yang digunakan pada penelitian ini adalah cangkul parang, arit, meteran, gembor, timbangan analitik dan sebagainya.

Pada penelitian ini menggunakan Rancangan Acak Kelompok (RAK) non faktorial yang terdiri dari 6 perlakuan dan 3 kelompok sehingga terdapat 18 unit satuan percobaan. Tanah yang digunakan adalah tanah ultisol, maka takaran kompos ditingkatkan dari rekomendasi pupuk organik secara umum yaitu 20 ton/Ha dan ditambah dengan penggunaan pupuk anorganik 100\%. Adapun rekomendasi pupuk anorganik yang digunakan pada tanaman kedelai pada penelitian ini adalah berdasarkan rekomendasi PT. Petro Kimia Gresik yang menggunakan pemupukan berimbang yaitu: Urea $75 \mathrm{~kg} / \mathrm{ha}, \mathrm{SP}-36100 \mathrm{~kg} / \mathrm{ha}$ dan $\mathrm{KCl} 50 \mathrm{~kg} / \mathrm{ha}$. Perlakuan yang diberikan adalah:

$$
\begin{aligned}
& A=\text { Tanpa masukan apapun }(\text { kontrol) } \\
& B=\text { KOTAKPLUS } 10 \text { ton/ha }+100 \% \text { pupuk anorganik } \\
& \text { C }=\text { KOTAKPLUS } 20 \text { ton } / \mathrm{ha}+100 \% \text { pupuk anorganik } \\
& D=\text { KOTAKPLUS } 30 \text { ton/ha }+100 \% \text { pupuk anorganik } \\
& E=\text { Kompos TKKS saja } 20 \text { ton/ha }+100 \% \text { pupuk anorganik } \\
& F=100 \% \text { pupuk anorganik }
\end{aligned}
$$

\section{Analisis Data}

Hasil penelitian ini diuji secara statistik pada tabel ANOVA, yaitu apabila nilai $\mathrm{F}$ hitung lebih besar dari $\mathrm{F}$ tabel pada taraf 5\% atau berpengaruh nyata, maka dilanjutkan dengan uji lanjut Beda Nyata Jujur (BNJ).

\section{Pelaksanaan Penelitian}

Pada penelitian ini kompos yang dibuat ada dua jenis yaitu kompos tandan kosong kelapa sawit plus (KOTAKPLUS) dan kompos TKKS saja. Untuk kompos tandan kosong kelapa sawit saja menggunakan bahan $100 \%$ tandan kosong kelapa sawit. Penelitian ini masing-masing telah dibuat $30 \mathrm{~kg}$ kompos, maka untuk kompos tandan kosong kelapa sawit saja disediakan bahan tandan kosong kelapa sawit kering 100\% $(30 \mathrm{~kg})$. Kemudian untuk bahan-bahan yang digunakan untuk pembuatan $30 \mathrm{~kg}$ KOTAKPLUS adalah tandan kosong kelapa sawit (yang telah dicacah dengan menggunakan parang pencacah) $75 \%$ (22,5 kg), kotoran 
ayam kering $15 \%(4,5 \mathrm{~kg})$, dan untuk mempercepat proses dekomposisi kedua jenis kompos diberi kapur 10 $\%$ dari berat total bahan kompos yaitu $3 \mathrm{~kg}$ kapur dolomit, kemudian diberi EM4 0,1\% (100 ml/ $30 \mathrm{~kg}$ bahan kompos). Adapun kandungan sifat kimia kompos yang digunakan pada penelitian ini dapat diihat pada tabel.1

Tabel 1. Hasil analisis kandungan unsur hara kompos KOTAKPLUS dan kompos TKKS saja

\begin{tabular}{ccc}
\hline Kandungan Unsur hara & Kompos KOTAKPLUS & Kompos TKKS saja \\
\hline $\mathrm{pH}$ & 10,1 & 9,41 \\
C-Organik & 21,06 & 14,19 \\
$\mathrm{~N}$ & 0,94 & 6,28 \\
$\mathrm{P}$ & 2,19 & 1,88 \\
$\mathrm{~K}$ & 2,94 & 2,51 \\
$\mathrm{Ca}$ & 6,24 & 5,04 \\
$\mathrm{Mg}$ & 2,19 & 1,61 \\
C/N ratio & 22,40 & 2,26 \\
KA & 132,42 & 112,36 \\
\hline
\end{tabular}

\section{Parameter Pengamatan}

Parameter pengamatan tanaman meliputi: Tinggi tanaman umur 14, 28 dan 42 HST, jumlah polong pertanaman (buah), berat biji pertanaman (gram), dan berat 100 biji (gram). Semua data hasil penelitian di analisis secara statistik, kemudian disajikan dalam bentuk tabel.

\section{HASIL DAN PEMBAHASAN}

\section{Tinggi Tanaman (cm)}

Berdasarkan hasil analisis sidik ragam parameter pengamatan tinggi tanaman kedelai pada umur 14, 28, 42 HST dan uji lanjut BNJ taraf $5 \%$ menunjukkan bahwa pemberian pupuk kompos KOTAKPLUS berpengaruh nyata terhadap tinggi tanaman kedelai 14, 28 dan 42 HST. Rata - rata tinggi tanaman kedelai umur 14, 28, 42 HST dapat dilihat pada tabel 2.

Tabel 2. Tinggi tanaman kedelai 14, 28, 42 HST yang dipengaruhi oleh pemberian pupuk kompos KOTAKPLUS

\begin{tabular}{lccc}
\hline \multicolumn{1}{c}{ Perlakuan } & $14 \mathrm{HST}$ & $28 \mathrm{HST}$ & $42 \mathrm{HST}$ \\
\hline $\mathrm{A}$ = Kontrol & $8,14^{\mathrm{c}}$ & $22,93^{\mathrm{c}}$ & $55,87^{\mathrm{c}}$ \\
$\mathrm{B}$ = KOTAKPLUS 10 ton/ha + 100\% pupuk anorganik & $8,67^{\mathrm{bc}}$ & $27,01^{\mathrm{bc}}$ & $66,45^{\mathrm{bc}}$ \\
$\mathrm{C}$ = KOTAKPLUS 20 ton/ha + 100\% pupuk anorganik & $9,10^{\mathrm{ab}}$ & $28,30^{\mathrm{ab}}$ & $70,37^{\mathrm{ab}}$ \\
$\mathrm{D}$ = KOTAKPLUS 30 ton/ha + 100\% pupuk anorganik & $9,75^{\mathrm{a}}$ & $30,44^{\mathrm{a}}$ & $72,74^{\mathrm{a}}$ \\
$\mathrm{E}$ = TKKS saja 20 ton/ha + 100\% pupuk anorganik & $8,60^{\mathrm{bc}}$ & $26,57^{\mathrm{bc}}$ & $63,93^{\mathrm{c}}$ \\
$\mathrm{F}$ = 100\% pupuk anorganik & $8,18^{\mathrm{c}}$ & $25,54^{\mathrm{c}}$ & $62,26^{\mathrm{c}}$ \\
\hline
\end{tabular}

Keterangan: Nilai rata-rata yang diikuti oleh huruf kecil yang sama, menunjukkan tidak berbeda nyata pada uji BNJ taraf $5 \%$

Pada tabel 2 menunjukkan bahwa rata - rata tinggi tanaman pada umur 14, 28, 42 HST yang tertinggi adalah pada perlakuan D yaitu $9,75 \mathrm{~cm}, 30,44 \mathrm{~cm}$, dan $72,74 \mathrm{~cm}$. Nilai tersebut tidak berbeda nyata dengan perlakuan A, B, C, E dan F. Pemberian pupuk kompos KOTAKPLUS 30 ton/Ha $+100 \%$ pupuk anorganik terlihat dapat meningkatkan tinggi tanaman dibandingkan dengan tanpa perlakuan kontrol yaitu pada tanah ultisol yang sangat rendah unsur hara dan kandungan bahan organik. Pemberian pupuk berimbang anorganik urea, SP-36 dan $\mathrm{KCl}$ dapat menstimulasi pertumbuhan vegetatif tanaman dan menguatkan sistem perakaran pada tanaman, maka dapat memacu pertumbuhan tinggi tanaman kedelai.

Parameter tinggi tanaman ini sangat dipengaruhi oleh kandungan kompos yang digunakan pada penelitian ini, dimana pada kompos KOTAKPLUS C-organik 21,06 \% sedangkan kompos TKKS saja 14,19\%. Dan juga kandungan $\mathrm{P}$, K kompos KOTAKPLUS lebih tinggi dibandingkan dengan kompos TKKS saja. Bariyanto et al, (2015) menyatakan bahwa pemberian 20 ton/Ha kompos TKKS dapat meningkatkan tinggi bibit kelapa sawit 13,5 cm. Menurut Indriani (2003), kompos mempunyai beberapa sifat yang menguntungkan yaitu memperbaiki struktur tanah berlempung sehingga menjadi ringan, memperbesar daya 
ikat tanah berpasir sehingga tanah tidak berderai, menambah daya ikat air dan tanah, memperbaiki drainase dan tata udara dalam tanah, mempertinggi daya ikat tanah terhadap zat hara.

Jumlah Polong Pertanaman (buah)

Berdasarkan hasil analisis sidik ragam parameter pengamatan jumlah polong pertanaman tanaman kedelai dan uji lanjut BNJ taraf $5 \%$ menunjukkan bahwa pemberian pupuk kompos KOTAKPLUS berpengaruh nyata terhadap jumlah polong pertanaman. Rata-rata jumlah polong pertanaman tanaman kedelai dapat dilihat pada tabel 3

Tabel 3. Jumlah polong pertanaman (buah) yang dipengaruhi oleh pemberian pupuk komposKOTAKPLUS

\begin{tabular}{lc}
\hline \multicolumn{1}{c}{ Perlakuan } & Rata - rata jumlah polong pertanaman (buah) \\
\hline $\mathrm{A}=$ Kontrol & $46,51^{\mathrm{e}}$ \\
$\mathrm{B}=$ KOTAKPLUS 10 ton/ha $+100 \%$ pupuk anorganik & $55,12^{\mathrm{c}}$ \\
$\mathrm{C}=$ KOTAKPLUS 20 ton/ha $+100 \%$ pupuk anorganik & $59,28^{\mathrm{b}}$ \\
$\mathrm{D}=$ KOTAKPLUS 30 ton/ha $+100 \%$ pupuk anorganik & $64,09^{\mathrm{a}}$ \\
$\mathrm{E}=$ TKKS saja 20 ton/ha $+100 \%$ pupuk anorganik & $53,03^{\mathrm{cd}}$ \\
$\mathrm{F}=100 \%$ pupuk anorganik & $49,76^{\mathrm{de}}$ \\
\hline
\end{tabular}

Keterangan: Nilai rata-rata yang diikuti oleh huruf kecil yang sama, menunjukkan tidak berbeda nyata pada uji BNJ taraf $5 \%$

Pada tabel 3 data analisis jumlah polong pertanaman menunjukkan bahwa rata-rata jumlah polong pertanaman yang tertinggi adalah pada perlakuan D (KOTAKPLUS 30 ton/Ha $+100 \%$ pupuk anorganik) yaitu 64,09 buah. Nilai tersebut berbeda nyata juga dengan perlakuan $\mathrm{C}$, dan tidak berbeda nyata dengan perlakuan B, A, dan F. pada perlakuan kontrol hanya 46,51 buah. Penambahan pupuk kompos KOTAKPLUS pada perlakuan $\mathrm{B}, \mathrm{C}, \mathrm{D}$, dibandingkan dengan perlakuan $\mathrm{E}$ kompos TKKS saja terdapat peningkatan jumlah polong pertanaman sekitar 8,61 - 17,58 gram pertanaman. Hal ini terlihat jelas bahwa tanah ultisol sangat rendah kandungan bahan organik nya. Kandungan unsur hara $\mathrm{P}$ pada pupuk kompos KOTAKPLUS yaitu sebesar 2,19 yang dapat memacu pertumbuhan bunga dan polong. Hasil penelitian Kurniawan et al 2014, peran unsur hara $\mathrm{P}$ dapat dimanfaatkan oleh tanaman secara optimal untuk peningkatan jumlah polong kedelai. Tinggi nya jumlah polong pertanaman pada perlakuan D (KOTAKPLUS 30 ton/Ha $+100 \%$ pupuk anorganik) karena kandungan unsur hara makro seperti $\mathrm{P}$ dan $\mathrm{K}$ pada pupuk kompos KOTAKPLUS yang mampu memacu pertumbuhan generative tanaman kedelai. Semakin tinggi K maka pembentukan dan pengisian polong semakin sempurna (Hanibal et al, 2001).

\section{Berat Biji Pertanaman (gram)}

Berdasarkan hasil analisis sidik ragam parameter pengamatan berat biji pertanaman tanaman kedelai dan uji lanjut BNJ taraf $5 \%$ menunjukkan bahwa pemberian pupuk kompos KOTAKPLUS berpengaruh nyata terhadap berat biji pertanaman. Rata-rata berat biji pertanaman tanaman kedelai dapat dilihat pada tabel 4 .

Tabel 4. Berat biji pertanaman (gram) yang dipengaruhi oleh pemberian pupuk kompos KOTAKPLUS

\begin{tabular}{lc}
\hline \multicolumn{1}{c}{ Perlakuan } & Rata - rata berat biji pertanaman (gram) \\
\hline $\mathrm{A}$ = Kontrol & $6,25^{\mathrm{e}}$ \\
$\mathrm{B}$ = KOTAKPLUS 10 ton/ha $+100 \%$ pupuk anorganik & $11,15^{\mathrm{c}}$ \\
C = KOTAKPLUS 20 ton/ha $+100 \%$ pupuk anorganik & $12,10^{\mathrm{b}}$ \\
$\mathrm{D}$ = KOTAKPLUS 30 ton/ha $+100 \%$ pupuk anorganik & $13,68^{\mathrm{a}}$ \\
$\mathrm{E}$ = TKKS saja 20 ton/ha $+100 \%$ pupuk anorganik & $9,85^{\mathrm{d}}$ \\
$\mathrm{F}$ = 100 \% pupuk anorganik & $6,77^{\mathrm{e}}$ \\
\hline
\end{tabular}

Keterangan: Nilai rata-rata yang diikuti oleh huruf kecil yang sama, menunjukkan tidak berbeda nyata pada uji BNJ taraf $5 \%$

Data analisis berat biji pertanaman menunjukkan bahwa rata-rata berat biji pertanaman yang tertinggi adalah pada perlakuan D (KOTAKPLUS 30 ton/Ha $+100 \%$ pupuk anorganik) yaitu dengan berat 13,68 gram. Nilai tersebut berbeda nyata dengan perlakuan $\mathrm{C}$ dan B. Berat biji pertanaman yang terendah adalah terdapat pada perlakuan A (kontrol) yaitu 6,25 gram. Penyebab rendahnya berat biji pertanaman pada perlakuan A (kontrol) disebabkan oleh sangat redahnya kandungan bahan organik dan kurangnya unsur hara $\mathrm{P}$ dan K pada tanah ultisol.

Penambahan pupuk kompos KOTAKPLUS pada perlakuan B, C, D, dibandingkan dengan perlakuan E kompos TKKS saja terdapat peningkatan berat biji pertanaman sekitar 1,3 - 3,83 gram pertanaman. Hal ini 
disebabkan karena pupuk kompos KOTAKPLUS diperkaya oleh kandungan unsur hara $\mathrm{P}$ dan $\mathrm{K}$ yaitu sebesar 2,19 \% dan 2,94 \%. Kandungan P pada pupuk kompos KOTAKPLUS disumbangkan oleh kotoran ayam dan kandungan $\mathrm{K}$ disumbangkan oleh kandungan tandan kosong kelapa sawit. Pemberian pupuk yang berimbang merupakan kunci peningkatan efisensi penggunaan pupuk dan ingkat produktivitas tanaman.
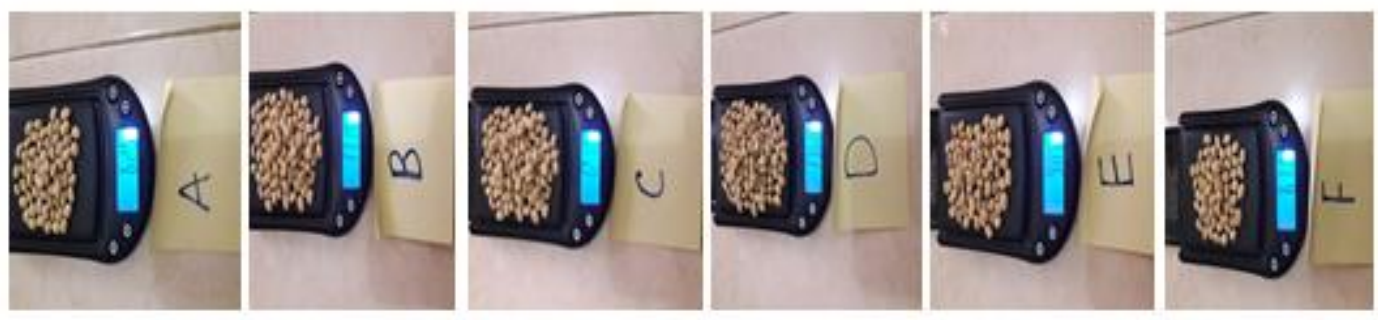

Gambar 1. Berat Biji Pertanaman Akibat Penambahan KOTAKPLUS (Gram)

\section{Berat 100 Biji (gram)}

Berdasarkan hasil analisis sidik ragam parameter pengamatan berat 100 biji tanaman kedelai dan uji lanjut BNJ taraf $5 \%$ menunjukkan bahwa pemberian pupuk kompos KOTAKPLUS berpengaruh nyata terhadap berat 100 biji. Rata-rata berat 100 biji tanaman kedelai dapat dilihat pada tabel.5.

Tabel 5. Berat 100 biji (gram) yang dipengaruhi oleh pemberian pupuk kompos KOTAKPLUS.

\begin{tabular}{lc}
\hline \multicolumn{1}{c}{ Perlakuan } & Rata - rata berat 100 biji (gram) \\
\hline $\mathrm{A}=$ Kontrol & $9,42^{\text {cd }}$ \\
$\mathrm{B}=$ KOTAKPLUS 10 ton/ha $+100 \%$ pupuk anorganik & $10,90^{\mathrm{c}}$ \\
$\mathrm{C}=$ KOTAKPLUS 20 ton/ha $+100 \%$ pupuk anorganik & $12,85^{\mathrm{b}}$ \\
$\mathrm{D}=$ KOTAKPLUS 30 ton/ha $+100 \%$ pupuk anorganik & $14,63^{\mathrm{a}}$ \\
$\mathrm{E}=$ TKKS saja 20 ton/ha $+100 \%$ pupuk anorganik & $10,68^{\mathrm{cd}}$ \\
$\mathrm{F}=100 \%$ pupuk anorganik & $9,74^{\text {cd }}$ \\
\hline
\end{tabular}

Keterangan: Nilai rata-rata yang diikuti oleh huruf kecil yang sama, menunjukkan tidak berbeda nyata pada uji BNJ taraf $5 \%$

Data analisis berat 100 biji menunjukkan bahwa rata-rata berat 100 biji yang tertinggi adalah pada perlakuan D (KOTAKPLUS 30 ton/Ha $+100 \%$ pupuk anorganik) yaitu dengan berat 14,63 gram. Nilai tersebut berbeda nyata dengan perlakuan $\mathrm{C}$ dan $\mathrm{B}$. Berat 100 biji yang terendah adalah terdapat pada perlakuan A (kontrol) yaitu 9,42 gram. Dari hasil penelitian ini bahwa pemberian pupuk kompos KOTAKPLUS 30 ton/ha $+100 \%$ pupuk anorganik dapat meningkatkan berat 100 biji tanaman kedelai yaitu sebesar 14,63 gram dan sudah melebihi deskripsi berat 100 biji yaitu 13,00 gram. Hal ini tidak terlepas dari peranan pupuk komos KOTAKPLUS yang diperkaya oleh kandungan $\mathrm{P}$ dan $\mathrm{K}$ serta $\mathrm{C}$-organik pada KOTAKPLUS yang mampu meningkatkan berat 100 biji pada tanaman kedelai. Pemberian pupuk organik KOTAKPLUS dan pemupukan yang berimbang pada tanah ultisol merupakan paduan dalam melakukan pengelolaan unsur hara pada tanah ultisol yang mempunyai tahap jangka panjang yang mampu meningkatkan kesuburan dan kualitas tanah ultisol untuk mencapai system pertanian yang berkelanjutan. Hardjowigeno (2010) mengatakan bahwa unsur hara $\mathrm{P}$ berperan dalam pembentukan biji sedangkan unsur hara $\mathrm{K}$ mempunyai peran dalam pembentukan karbohidrat.

\section{KESIMPULAN}

Berdasarkan hasil penelitian yang telah dilakukan dapat simpulkan bahwa dosis pemberian pupuk kompos KOTAKPLUS dalam meningkatkan pertumbuhan dan produksi tanaman kedelai pada tanah ultisol adalah 30 ton/ha $+100 \%$ pupuk anorganik dengan Tinggi tanaman umur $14 \mathrm{HST}$ adalah 9,75 cm, $28 \mathrm{HST}$ adalah $30,44 \mathrm{~cm}, 42 \mathrm{HST}$ adalah $72,74 \mathrm{~cm}$. Kemudian jumlah polong pertanaman adalah 64,09 , berat biji pertanaman adalah 13,68 gram, dan berat 100 biji adalah 14,63 gram.

\section{UCAPAN TERIMA KASIH}

Alhamdulillah kami mengucapkan terimakasih kepada Direktorat Jenderal Penguatan Riset dan Pengembangan Kementerian Riset Teknologi dan Pendidikan Tinggi Republik Indonesia yang telah 
membiayai sepenuhnya penelitian dosen pemula ini, Rektor UNIKS, LPPM UNIKS, Dekan Faperta UNIKS, Dinas Pertanian Kabupaten Kuansing, serta semua pihak yang telah banyak membantu dalam penelitian ini.

\section{DAFTAR PUSTAKA}

Badan Pusat Statistik. 2015. Data Produksi Padi, Jagung, dan Kedelai Provinsi Riau. Riau: Berita Resmi Statistik.

Bariyanto, Nelvia, Wardati. 2015. Pengaruh Pemberian Kompos Tandan Kosong Kelapa Sawit (TKKS) Pada Pertumbuhan Bibit Kelapa Sawit (Elaeis Guineensis Jacq) di Main Nursery pada Medium Subsoil Ultisol. Jom Faperta Universitas Riau 2(1): 1-13.

Darmosarkoro, W dan Winarna. 2007. Penggunaan TKS dan Kompos TKS untuk Meningkatkan Pertumbuhan dan Produksi Tanaman. Jurnal Lahan dan Pemupukan Kelapa Sawit Edisi 1. C4:181-194.

Fauzi, Y., Y.E. Widyastuti, I. Satyawibawa, dan R. Hartono. 2008. Kelapa Sawit: Budidaya, Pemanfaatan Limbah dan Hasil, dan Analisis Usaha dan Pemasaran. Jakarta: Penebar Swadaya.

Hakim, N. 2006. Pengelolaan Kesuburan Tanah Masam dengan Teknologi Pengapuran Terpadu. Padang: Andalas University Press.

Hanibal, Sarman dan Gusniwati. 2001.Pemanfaatan Abu Janjang Kelapa Sawit pada Lahan Kering dan Pengaruhnya Terhadap Pembentukan Nodula Akar Pertumbuhan dan Hasil Tanaman Kedelai (Glaycine max). Skipsi. Jambi: Fakultas Pertanian Universitas Jambi.

Hardjowigeno, S. 2010. Ilmu Tanah. Jakarta: Akademi Presindo.

Indriani, Y.H. 2003.Membuat Kompos Secara Kilat. Jakarta: Penebar Swadaya.

Kurniawan, S., A. Raysad dan Wardati, 2014. Pengaruh Pemberian Pupuk Posfor Terhadap Pertumbuhan Beberapa Varietas Kedelai (Glycine max (L.)Merril). JOM Faperta Universitas Riau 1(2): 1-11. 